\title{
Public Health Awards
}

\author{
_. Supplemental List__
}

HOMER N. CALVER, B.S.

$\mathrm{T}$ THIS supplemental list of public health awards brings up to date, as of August 15, 1957, the analysis published in the January 1956 issue of Public Iealth Reports (pl). 6266). Here as there the list inclucles a wards to lay individuals and persons connected with communication media for contributions to public health or the popular understanding thereof. (Omitted are the following categories of honors: (a) those not primarily intended for services in the field of public health unless a public health worker has as much chance of winning the award as cloes a member of another profession; (b) those given for length of service or

Mr. Calver is secretary of the Public Health Committee of the Paper Cup and Container Institute and editor of its Health Officers News Digest. Robert E. Mytinger, assistant to the secretary, tabulated the awards. length of membership: (c) those given for published papers describing research as distinct from those for the research itself; $(d)$ those given to former officers and members for service to the organization; (e) election to Delta Omega or to other honorary societies; $(f)$ scholarships and fellowships; $(g)$ honorary lectureships.

One award has been dropped from the list and 18 added (see table). I few minor changes in the original listing are noted below:

- The American Hospital Issociation Award of Merit is now known as the Distinguished Service Award.

- The Axson-(Choppin Award originally restricted to a citizen not comnected with a health department is now given to an individual not in full-time employment of an official public health agency.

- The Bell Award trophy is now a plaque.

\section{Public Health Awards Added to the 1956 List}

\begin{tabular}{|c|c|c|c|}
\hline Name, sponsor, and administrator ${ }^{1}$ & Type ${ }^{2}$ & Eligibility for award & Basis \\
\hline $\begin{array}{l}\text { Abel Award. Eli Lilly \& Co. (S). } \\
\text { American Society for Pharma- } \\
\text { cology and Experimental Thera- } \\
\text { peutics (A). }\end{array}$ & $\begin{array}{l}\$ 1,000 \text { at irregu- } \\
\text { lar intervals. }\end{array}$ & Researchers ..... & $\begin{array}{l}\text { Excellence in research for persons } \\
\text { under } 35 \text { years of age. }\end{array}$ \\
\hline $\begin{array}{l}\text { Appert Medal. Institute of Food } \\
\text { Technologists, Chicago Section } \\
\text { (S, A). }\end{array}$ & Medal..... & $\begin{array}{l}\text { Members and non- } \\
\text { members. }\end{array}$ & $\begin{array}{l}\text { Outstanding accomplishments in } \\
\text { food technology. }\end{array}$ \\
\hline $\begin{array}{l}\text { Barton Memorial Award. Louisi- } \\
\text { ana Public Health Association } \\
\text { (S, A). }\end{array}$ & Certificate $\ldots$ & Unrestricted & $\begin{array}{l}\text { Significant achievement in re- } \\
\text { search, scholarship or outstand- } \\
\text { ing pioneering performance in } \\
\text { public health in Louisiana. }\end{array}$ \\
\hline $\begin{array}{l}\text { Blackwell (Elizabeth) Medal. } \\
\text { American Medical Women's As- } \\
\text { sociation (S, A). }\end{array}$ & Medal _. & Members_._. & $\begin{array}{l}\text { Distinguished member of the as- } \\
\text { sociation for contribution to } \\
\text { medicine, public welfare, or the } \\
\text { association. }\end{array}$ \\
\hline $\begin{array}{l}\text { Bryant Award. Texas Public } \\
\text { Health Association }(\mathrm{S}, \mathrm{A}) .\end{array}$ & $\begin{array}{l}\text { Scroll and trip to } \\
\text { APHA annual } \\
\text { meeting. }\end{array}$ & Inrestricted. & $\begin{array}{l}\text { Outstanding public health } \\
\text { achievements. }\end{array}$ \\
\hline
\end{tabular}




\section{Public Health Awards Added to the 1956 List-Continued}

\begin{tabular}{|c|c|c|c|}
\hline Name, sponsor, and administrator ${ }^{1}$ & Type ${ }^{2}$ & Eligibility for award & Bas:s \\
\hline $\begin{array}{l}\text { Formento Memorial Award. Lou- } \\
\text { isiana Public Health Association } \\
\text { (S, A). }\end{array}$ & Certificate $\ldots$ & $\begin{array}{l}\text { Individual not in } \\
\text { full time employ- } \\
\text { ment by official } \\
\text { public health } \\
\text { agency. }\end{array}$ & $\begin{array}{l}\text { Meritorious activity to foster the } \\
\text { program or any phase thercof } \\
\text { in any area of Louisiana. }\end{array}$ \\
\hline $\begin{array}{l}\text { Indiana Public Health Association } \\
\text { Award. Indiana Public Health } \\
\text { Association (S, A). }\end{array}$ & Plaque...... & Unrestricted ....... & $\begin{array}{l}\text { Outstanding service in the ficld } \\
\text { of public health. }\end{array}$ \\
\hline $\begin{array}{l}\text { Lasker Award. Albert and Mary } \\
\text { Lasker Foundation (S, A). }\end{array}$ & $\begin{array}{l}\$ 2,000, \text { scroll and } \\
\text { statuette; } 3 \text { per } \\
\text { year. }\end{array}$ & $\begin{array}{l}\text { Journalists and com- } \\
\text { mentators. }\end{array}$ & $\begin{array}{l}\text { Outstanding reporting on medi- } \\
\text { cal rcsearch and public health } \\
\text { in newspapers, magazines, ra- } \\
\text { dio, TV. }\end{array}$ \\
\hline $\begin{array}{l}\text { Lasker Award. Albert and Mary } \\
\text { Lasker Foundation (S). Planned } \\
\text { Parenthood Federation of Amer- } \\
\text { ica (A). }\end{array}$ & $\begin{array}{l}\$ 500 \text { and scroll; } \\
\text { irregular as mer- } \\
\text { ited. }\end{array}$ & $\begin{array}{l}\text { Health officers, phy- } \\
\text { sicians, adm inis- } \\
\text { trators, health edu- } \\
\text { cators. }\end{array}$ & $\begin{array}{l}\text { Outstanding leadership in fur- } \\
\text { thering the cause of planned } \\
\text { parenthood. }\end{array}$ \\
\hline $\begin{array}{l}\text { Mangold (Outstanding Sanitarian) } \\
\text { Award. National Association of } \\
\text { Sanitarians (S, A). }\end{array}$ & $\begin{array}{l}\text { Medallion and } \\
\text { plaque to the } \\
\text { department } \\
\text { for } 1 \text { year. }\end{array}$ & Members...... & $\begin{array}{l}\text { Active environmental sanitarian } \\
\text { who has performed duties in } \\
\text { an exceptional manner, such as } \\
\text { raising the status of the pro- } \\
\text { fession. }\end{array}$ \\
\hline $\begin{array}{l}\text { McCormack Award. Association } \\
\text { of State and Territorial Health } \\
\text { Officers (S, A). }\end{array}$ & $\begin{array}{l}\text { Scroll; no set } \\
\text { number. }\end{array}$ & - . - do & $\begin{array}{l}\text { Service in public health } 25 \text { years } \\
\text { or more, at least } 10 \text { as State } \\
\text { health officer, and with one or } \\
\text { more major accomplishments } \\
\text { to his credit in administration } \\
\text { or research related to public } \\
\text { health. }\end{array}$ \\
\hline $\begin{array}{l}\text { McIver (Pearl) Public Health } \\
\text { Nurse Award. American Nurses } \\
\text { Association }(\mathrm{S}, \mathrm{A}) .\end{array}$ & $\begin{array}{l}\text { Medallion; one } \\
\text { every } 2 \text { years. }\end{array}$ & Public health nurses. & Outstanding public health nurse. \\
\hline $\begin{array}{l}\text { New Mexico Public Health Asso- } \\
\text { ciation (Public Health Worker) } \\
\text { Award. New Mexico Public } \\
\text { Health Association (S, A). }\end{array}$ & Metal platter & $\begin{array}{l}\text { Member of official } \\
\text { or voluntary pub- } \\
\text { lic health unit. }\end{array}$ & $\begin{array}{l}\text { Outstanding service to the cause } \\
\text { of public health in the State } \\
\text { of New Mexico. }\end{array}$ \\
\hline $\begin{array}{l}\text { Oklahoma Public Health Associa- } \\
\text { tion Award. Oklahoma Public } \\
\text { Health Association (S, A). }\end{array}$ & Plaque & Members .......... & $\begin{array}{l}\text { Outstanding work in the field of } \\
\text { public health. }\end{array}$ \\
\hline $\begin{array}{l}\text { Oregon Public Health Association } \\
\text { Award. Oregon Public Health } \\
\text { Association (S, A). }\end{array}$ & do & $\begin{array}{l}\text { Individual public } \\
\text { health workers, } \\
\text { voluntary agency } \\
\text { executives, and } \\
\text { lay volunteers. }\end{array}$ & $\begin{array}{l}\text { Outstanding contributions in the } \\
\text { field of public health in Oregon. }\end{array}$ \\
\hline $\begin{array}{l}\text { West Virginia Public Health Asso- } \\
\text { ciation Award. West Virginia } \\
\text { Public Health Association (S, } \\
\text { A). }\end{array}$ & $\ldots \ldots$ do & $\begin{array}{l}\text { Public health per- } \\
\text { sonnel. }\end{array}$ & $\begin{array}{l}\text { Outstanding achievement } \\
\text { public health in State. }\end{array}$ \\
\hline $\begin{array}{l}\text { West Virginia Public Health Asso- } \\
\text { ciation Award. West Virginia } \\
\text { Public Health Association (S, } \\
\text { A). }\end{array}$ & _. do & Any citizen........ & $\begin{array}{l}\text { Outstanding achievement for } \\
\text { public health in State. }\end{array}$ \\
\hline $\begin{array}{l}\text { Winslow, C.-E. A., Award. Con- } \\
\text { necticut Public Health Associ- } \\
\text { ation (S, A). }\end{array}$ & do & $\begin{array}{l}\text { Public health work- } \\
\text { ers and agencies. }\end{array}$ & $\begin{array}{l}\text { Outstanding achievement in pub- } \\
\text { lic health in Connecticut. }\end{array}$ \\
\hline
\end{tabular}

${ }^{1} \mathrm{~S}$-Sponsor; A-Administrator.

${ }^{2}$ Except as noted, 1 award is given each year. 
- The Crumbine Awards medals are now medallions.

- The Florida Sanitarians Scroll is now the Florida Association of Milk and Food Sanitarians Scroll.

- The Massachusetts Association of Sanitarians Scroll has been discontinued.

- The North Carolina Public Health Association Award citation certificate is now a plaque.

- The Rankin Award trophy has been changed to a plaque.

- The Reynolds Award trophy has been changed to a plaque.

- The Ross Medal given by the National Tuberculosis Association may now be awarded to medical practitioners and scientists as well as to those outside.

- The Shattuck Award originally one award is now approximately six per year.

- The Sippy Award is no longer restricted to the members of the district in which the annual meeting of the Western Branch of the American Public Health Association is held.

- The White Memorial Award plaque has been changed to a scroll and is restricted to a full-time employee of any official health agency instead of to any member of the State department of health.

- The honorarium of the original 3 Lasker Awards has been doubled and 2 more awards, 1 of lesser value, have been set up.

\section{Reactions to Penicillin}

The number of serious reactions to penicillin has been increasing each year according to Dr. Henry Welch, chief, Division of Antibiotics, Food and Drug Administration, reporting before the Fifth Annual Symposium on Antibiotics, October 3, 1957.

A substantially higher number of reactions to penicillin than to other antibiotics were discovered by an FDA survey, the first nationwide study of reactions to the principal antibiotics, covering a period from the latter part of 1953 to early 1957.

The number of reactions to penicillin is still small, Dr. Welch pointed out, when it is considered that millions of persons receive the drug each year and that it has saved tens of thousands of lives. The increased incidence of reactions, he added, is to be expected in the wide use of a highly antigenic substance.

The FDA survey was a geographic sampling of severe cases treated by more than 1,600 private physicians and covered 198,000 of the 685,000 general hospital beds available in this country. The survey was conducted by inspectors in the agency's 16 districts.

In the survey, 3,419 histories of severe reactions to all antibiotics were collected and classified. Of these, 424 were excluded from the tabulation because of insufficient data. One-third of the reported reactions were classified as life-threatening. Of these, 900 , the great majority, followed the use of penicillin. More than 600 of the most serious reactions resulted from penicillin by intramuscular injection. In 122 of these cases, penicillin was used in combination with streptomycin and dihydrostreptomycin.

Intramuscular injections were followed by 71 deaths from anaphylactoid shock, the most serious reaction. Anaphylactoid reactions occurred with about equal frequency in both sexes and in all adult age groups. The smallest number of these reactions occurred in children 12 years of age and under.

Although no physicians were found to be using penicillin indiscriminately, Dr. Welch thought that the trend in serious reactions indicated that there should be a clear-cut need before the drug is administered.

The complete report will appear in the December issue of Antibiotic Medicine and Clinical Therapy. FDA officials plan other dissemination. 